\title{
A Comparative Study of Preservation and Storage of Haemophilus influenzae
}

\section{Olga C Aulet de Saab, Marta C de Castillo ${ }^{+}$, Aida P de Ruiz Holgado, Olga $M$ de Nader}

Instituto de Microbiología “Dr. Luis C. Verna”, Facultad de Bioquímica, Química y Farmacia, Universidad Nacional de Tucumán, Ayacucho 491, (4000) San Miguel de Tucumán, Argentina

The aim of this study was to compare the efficacy of conservation by freezing the strains of Haemophilus influenzae at $-20^{\circ} \mathrm{C}$ and $-70^{\circ} \mathrm{C}$.

Skim milk supplemented with glucose, yeast extract and glycerol allowed highest viability of $\mathrm{H}$. influenzae both at $-20^{\circ} \mathrm{C}$ and $-70^{\circ} \mathrm{C}$ from the media analyzed. Trypticase soy broth and brain heart infusion broth supplemented with glycerol, allowed excellent recovery. Use of cotton swaps as supporting material, with or without addition of cryoprotective agents, did not modify $\mathrm{H}$. influenzae viability after six months of storage. Concentration of the initial inoculum positively affected viability when stored at $-20^{\circ} \mathrm{C}$. Initial concentration did not influence survival after storage at $-70^{\circ} \mathrm{C}$. Thawing at room temperature should not exceed 3 h as to get highest survival percentage.

Key words: Haemophilus influenzae - storage - culture media

Haemophilus influenzae is an etiological agent of a wide variety of infectious diseases in human beings, from non-complicated ones such as conjunctivitis and otitis media, to invasive, potentially life-threatening ones like bacterial meningitis and acute respiratory tract infections. This pathogen holds a serious agent responsible for numerous infections in paediatric patients in the Tucumán province, Argentina, mainly in infants less than two years of age.

It is very important to maintain strains isolated from this region viable, in order to observe physiopathogenic aspects, virulence factors and anti-microbial resistance. As these microorganisms are demanding in their nutrition requirements, they need well-supplemented, complex culture media for isolation. Due to the difficulties presented by $H$. influenzae with respect to its preservation and storage through time, an analysis of factors enhancing recovery of the microorganism after freezing has been proposed. Freezing is a very common way of preservation and storage of microorganisms (Calcott 1986).

This study received grants from CONICET (National Council of Scientific and Technical Research) and CIUNT (Research Council of Tucumán National University).

Corresponding author. Fax: 54-381-4248169

E-mail: microbiologia.clinica@unt.edu.ar

Received 11 July 2000

Accepted 22 November 2000
The aim of this study was to carry out a comparative study of the efficiency of preservation of $H$. influenzae at $-20^{\circ} \mathrm{C}$ and $-70^{\circ} \mathrm{C}$, evaluating the influence of (1) different suspension media, with or without addition of protective agents; (2) supporting material; (3) initial inoculum concentration; and (4) thawing time at room temperature of the stored strains. Statistical analysis of the results is given.

\section{MATERIALS AND METHODS}

Strain

This study was carried out with five $H$. influenzae type $\mathrm{b}$ strains, random by selected from isolates from clinical samples from patients treated for different infectious diseases at Niño Jesús Children's Hospital, Tucumán, Argentina.

Methodology - Samples were subjected to a direct bacteriological assay and then seeded on chocolate agar plates. Plates were incubated at 35$37^{\circ} \mathrm{C}$ for $24 \mathrm{~h}$ under a humid and $\mathrm{CO}_{2}(5-10 \%)$ atmosphere. Serological classification of the strains studied was carried out with monovalent antisera, using agglutination techniques (BactoHaemophilus influenzae Antiserum Type a, b, c, d, e and f, Difco (Campos 1999).

Suspension media and cryoprotective agents

Suspension media assayed were brain heart infusion broth (BHI) and trypticase soy broth (TSB), either with or without addition of one or more of the following cryoprotective agents: $4 \%$ milk, $6 \%$ lactose, $10 \%$ sucrose, or $25 \%$ glycerol. A third medium assayed consisted of $10 \%$ skim milk, supplemented with $1 \%$ glucose, $0.5 \%$ yeast extract and $10 \%$ glycerol (MGY). 
Methodology - Selected strains were transferred onto BHI chocolate agar, supplemented with $1 \%$ yeast extract (BYB), and incubated at $35-37^{\circ} \mathrm{C}$ for $24 \mathrm{~h}$. Microorganisms were then harvested, suspended at a concentration of $10^{15}$ cells $/ \mathrm{ml}$ in 0.3 $\mathrm{ml}$ of each suspension medium, supplemented or not with cryoprotective agents, and stored at $-20^{\circ} \mathrm{C}$ and $-70^{\circ} \mathrm{C}$. Viable cell counts were carried out after 0 (initial inoculum), 10, 30 and 60 days and 4, 6 and 12 months of storage to determine viability.

\section{Supporting material}

Cotton swaps were used as supporting material, either untreated or soaked in $\mathrm{BHI}+25 \%$ glycerol and MGY.

Methodology - A H. influenzae suspension of $10^{15} \mathrm{CFU} / \mathrm{ml}$ was obtained in $\mathrm{BHI} ; 0.1 \mathrm{ml}$ was seeded on BYB agar plates, spread with a Drigalsky spatula, and incubated at $35-37^{\circ} \mathrm{C}$ for $24 \mathrm{~h}$. With a single cotton swap $25 \%$ of the plated cultures was harvested; the swaps were then placed in sterile tubes and stored at $-20^{\circ} \mathrm{C}$ and $-70^{\circ} \mathrm{C}$. Viability was studied after $24 \mathrm{~h}$, and 1,2, 3 and 6 months of storage, placing the swaps in $1 \mathrm{ml}$ of BHI. Suspensions were homogenized by vortexing, and viable cell counts were carried out immediately afterwards.

Influence of initial inoculum concentration

$H$. influenzae viability at different initial inocula was studied in $\mathrm{BHI}+25 \%$ glycerol and MGY.

Methodology - Microorganisms were suspended at final concentrations of $10^{2}, 10^{4}, 10^{8}$ and $10^{15} \mathrm{CFU} / \mathrm{ml}$ in either of the media assayed; 0.3 $\mathrm{ml}$ of each concentration was stored at $-20^{\circ} \mathrm{C}$ and $-70^{\circ} \mathrm{C}$. Viable cell counts were carried out after $0 \mathrm{~h}$ (initial concentration), $24 \mathrm{~h}$, and 1,3 and 6 months of storage.

Influence of thawing at room temperature

Methodology - Suspensions of $H$. influenzae $\left(10^{15} \mathrm{CFU} / \mathrm{ml}\right)$ in $\mathrm{BHI}+25 \%$ glycerol were pre- pared and then $0.3 \mathrm{ml}$ aliquots were stored in cryovials at $-20^{\circ} \mathrm{C}$ and $-70^{\circ} \mathrm{C}$. After 30 days the samples were left at room temperature for 15,30 and 60 min, and 3, 6, 12, 24, 48 and $72 \mathrm{~h}$, avoiding agitation and formation of foam. Viable cell counts were carried out after each thawing time.

Viable cell counts - Viable cell counts were carried out in duplicate on BYB according to the technique by Clark et al. (1987).

Statistics - Factor analysis with three variables (Sigma Stat) was used to analyze the influence of suspension medium, protective agents, supporting material, initial inoculum concentration, and thawing at room temperature. Percentage of viability was studied at different temperatures and after different storage times.

\section{RESULTS}

Influence of suspension media and cryoprotective agents on survival of $H$. influenzae

Storage at $-20^{\circ} \mathrm{C}$ - Results are shown in Tables I and II. BHI and TSB without addition of cryoprotective agents as suspension media showed a substantial loss in viability; only 23.3 and $10 \%$ respectively was recovered after 60 days. The same media, but with addition of $25 \%$ glycerol, yielded a recovery of viable cells of 98 and $100 \%$ respectively after 60 days. After 12 months recovery dropped to $66 \%$ for BHI-glycerol and $68.6 \%$ for TSB-glycerol. Addition of sugars yielded a satisfactory recovery after four months of storage (between 60 and $73.3 \%$ ), decreasing to $42 \%$ or less after 12 months. Supplement of $4 \%$ milk demonstrated a similar behaviour. Addition of glycerol significantly increased survival of the microorganism through time. MGY as suspension medium yielded excellent viability after 12 months $(86.3 \%)$.

Storage at $-70^{\circ} \mathrm{C}-\mathrm{BHI}$ and TSB supplemented with sugars and/or glycerol allowed a $100 \%$ recovery of $H$. influenzae after 12 months of stor-

TABLE I

Influence of suspension medium and cryoprotective agents on survival of Haemophilus influenzae stored during 12 months at $-20^{\circ} \mathrm{C}$. Initial inoculum was $9 \times 1015 \mathrm{CFU} / \mathrm{ml}$

\begin{tabular}{lccccccc}
\hline & \multicolumn{7}{c}{ Recovery through time \% } \\
\cline { 2 - 7 } Suspension medium & $0 \mathrm{~h}$ & 10 days & 30 days & 60 days & 4 months & 6 months & 12 months \\
\hline BHI & 100 & 53.3 & 46.4 & 23.3 & 0 & 0 & 0 \\
BHI + 4\% milk & 100 & 98.6 & 93.3 & 73.3 & 52 & 46.6 & 20 \\
BHI + 10\% sucrose & 100 & 100 & 100 & 66 & 60 & 33.3 & 2 \\
BHI + 6\% lactose & 100 & 93.3 & 86.3 & 66 & 60 & 60 & 35.5 \\
BHI+ 25\% glycerol & 100 & 100 & 100 & 98 & 94 & 90 & 66 \\
BHI+ 4\% milk + 25\% glycerol & 100 & 100 & 100 & 100 & 80 & 75 & 60 \\
BHI+ 10\% sucrose + 25\% glycerol & 100 & 100 & 93 & 90 & 80 & 72.6 & 68.6 \\
BHI+ 6\% lactose + 25\% glycerol & 100 & 100 & 100 & 100 & 93.3 & 83.3 & 71.3 \\
MGY & 100 & 100 & 100 & 100 & 98 & 93.3 & 86.3 \\
\hline
\end{tabular}

BHI: brain heart infusion; MGY: $10 \%$ skim milk $+1 \%$ glucose $+0.5 \%$ yeast extract $+10 \%$ glycerol 
TABLE II

Influence of suspension medium and cryoprotective agents on survival of Haemophilus influenzae stored during 12 months at $-20^{\circ} \mathrm{C}$. Initial inoculum was 9x1015 CFU/ml

\begin{tabular}{lccccccc}
\hline & \multicolumn{7}{c}{ Recovery through time \% } \\
\cline { 2 - 8 } Suspension medium & $0 \mathrm{~h}$ & 10 days & 30 days & 60 days & 4 months & 6 months & 12 months \\
\hline TSB & 100 & 46.6 & 40 & 10 & 0 & 0 & 0 \\
TSB + 4\% milk & 100 & 100 & 100 & 86 & 68 & 54 & 14 \\
TSB + 10\% sucrose & 100 & 100 & 90 & 86 & 73.3 & 35.3 & 10 \\
TSB + 6\% lactose & 100 & 100 & 100 & 80 & 66.6 & 64.6 & 42 \\
TSB+ 25\% glycerol & 100 & 100 & 100 & 100 & 72.6 & 70 & 68.6 \\
TSB + 4\% milk +25\% glycerol & 100 & 100 & 100 & 100 & 90 & 72 & 62 \\
TSB + 10\% sucrose + 25\% glycerol & 100 & 100 & 100 & 90 & 86.6 & 80 & 53.3 \\
MGY & 100 & 100 & 100 & 100 & 98 & 93.3 & 86.3 \\
\hline
\end{tabular}

TSB: trypticase soy broth; MGY: $10 \%$ skim milk $+1 \%$ glucose $+0.5 \%$ yeast extract $+10 \%$ glycerol

age. After storage of BHI and TSB without supplements, viability of the microorganism was only $20 \%$ after one year (results not shown).

Factor analysis between suspension media with or without addition of cryoprotective agents, storage time and storage temperature revealed significant differences $(\mathrm{p}<0.001)$ in the percentage of survival of $H$. influenzae (results not shown).

Influence of supporting material

Statistical analysis showed no significant difference in viability of the strains stored at $-20^{\circ} \mathrm{C}$ and $-70^{\circ} \mathrm{C}$ with or without supporting material and supplemented or not with cryoprotective agents; and it was possible to recuperate more than $90 \%$ of the viable strains in all the cases after six months of storage (results not shown).

Influence of initial inoculum concentration

At $-20^{\circ} \mathrm{C}$ - At an initial concentration of 1015 $\mathrm{CFU} / \mathrm{ml}$ in $\mathrm{BHI}+25 \%$ glycerol or $\mathrm{MGY}, 90 \%$ was recovered after six months; more than $75 \%$ was recovered after three months at an initial concentration of $10^{8} \mathrm{CFU} / \mathrm{ml}$ in both media, supplemented with glycerol. Starting with an inoculum of $10^{2}$ $\mathrm{CFU} / \mathrm{ml}$ in $\mathrm{BHI}+25 \%$ glycerol or MGY, recovery percentages of 15 and 40 were obtained respectively after 6 months (Figs 1,2).

At $-70^{\circ} \mathrm{C}$ - Initial concentration and medium did not influence viability, because after six months a recovery of $100 \%$ was obtained for either medium and all the initial inocula assayed (results not shown).

Significant differences $(\mathrm{p}<0.001)$ in viability were observed for the various initial inocula when stored at $-20^{\circ} \mathrm{C}$. Storage at $-70^{\circ} \mathrm{C}$ did not show significant differences in survival for initial concentrations.

Influence of thawing at room temperature

Strains stored at $-20^{\circ} \mathrm{C}$ showed a recovery of more than $90 \%$ after thawing at room temperature for $3 \mathrm{~h}$. Viability decreased as thawing time in-

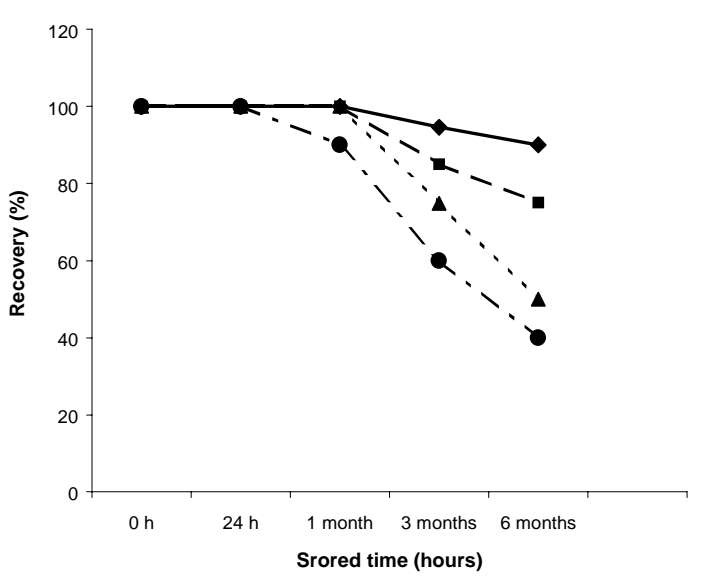

Fig.1: influence of initial cell concentration on survival of Haemophilus influenzae, preserved in brain heart infusion, supplemented with $25 \%$ glycerol and stored at $-20^{\circ} \mathrm{C} ; \bullet 10^{15}$ $\mathrm{CFU} / \mathrm{ml}, \boldsymbol{\square} 10^{8} \mathrm{CFU} / \mathrm{ml}, \mathrm{p} 10^{4} \mathrm{CFU} / \mathrm{ml}, \bullet 10^{2} \mathrm{CFU} / \mathrm{ml}$

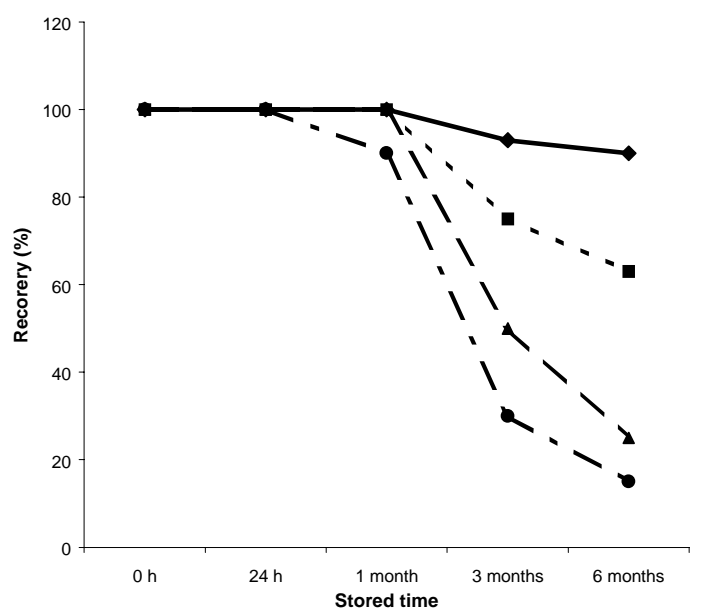

Fig. 2: influence of initial cell concentration on survival of Haemophilus influenzae, preserved in MGY (10\% skim milk $+1 \%$ glucose $+0.5 \%$ yeast extract $+10 \%$ glycerol $)$ and stored at $-20^{\circ} \mathrm{C} ; 10^{15} \mathrm{CFU} / \mathrm{ml}, \mathbf{a}_{10}^{8} \mathrm{CFU} / \mathrm{ml}, \mathrm{p} 10^{4} \mathrm{CFU} / \mathrm{ml}, \bullet$ $10^{2} \mathrm{CFU} / \mathrm{ml}$ 
creased, dropping to $59 \%$ after $12 \mathrm{~h}$ and disappearing completely after $24 \mathrm{~h}$. At $-70^{\circ} \mathrm{C}$ viability patterns were similar (Fig. 3).

Statistical analysis of the influence of thawing time at room temperature showed significant differences $(\mathrm{p}<0.001)$ for the percentage of $H$. influenzae survival both at $-20^{\circ} \mathrm{C}$ and $-70^{\circ} \mathrm{C}$.

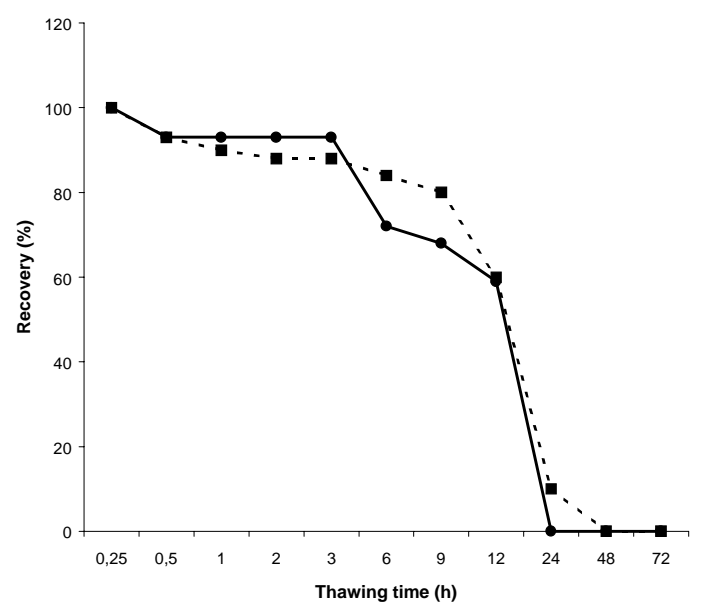

Fig. 3: influence of thawing time on survival of Haemophilus influenzae, preserved in brain heart infusion, supplemented with $25 \%$ glycerol and stored at $-20^{\circ} \mathrm{C}$ and $-70^{\circ} \mathrm{C}$ for 30 days; - $-20^{\circ} \mathrm{C},-70^{\circ} \mathrm{C}$

\section{DISCUSSION}

Use of cryoprotective agents in preservation media was first implemented in 1941 when Woodcock et al. used sugars in order to protect erythrocytes from freezing injury. Since that time numerous researchers have used different additives to enhance survival of frozen bacteria. Ling (1965), Merymann and Hornblower (1972), Pribor (1974) and Nei (1981) consider that freezing injury is less with addition of cryoprotective agents such as glycerol, sugar or milk, that inhibit intracellular iceforming during rapid freezing. Addition of carbohydrates decreases inactivation of dried Loctobacillus plantarum cells due to dehydration (Lievense et al. 1992, Leoni Linders et al. 1997). In our study addition of glycerol allowed hight recovery of the frozen microorganisms, with coincides with results obtained by Castillo et al. (1985).

Major (1953), Major et al. (1955) and Castillo et al. (1985) maintain that an increase in the initial cell concentration enhances the percentage of viable microorganisms after freezing, which agrees with our results.

During thawing alterations in cell wall permeability occur, and therefore careful precautions should be adopted. Agitation, foam formation and sudden temperature changes should be avoided, in order to prevent bacterial injury (Wagman 1960). Our results indicate that microorganisms should not be left for more than $3 \mathrm{~h}$ at room temperature in order to achieve highest recovery.

From the results obtained in the present study we recommend (a) starting with a concentrated inoculum; (b) suspending viable cells in MGY, BHI or TSB, the two latter ones supplemented with $25 \%$ glycerol; and (c) thawing at room temperature for not more than $3 \mathrm{~h}$ in order to obtain a satisfactory survival and assure preservation of $H$. influenzae strains through time at $-20^{\circ} \mathrm{C}$ and $-70^{\circ} \mathrm{C}$.

\section{ACKNOWLEDGEMENTS}

To Mr Eric Fengler for language advice and drawing of the graphics.

\section{REFERENCES}

Calcott PH 1986. Cryopreservation of microorganisms. CRC Crit Rev Biotechnol 4: 279-298.

Campos JM 1999. Haemophilus. In RP Murray, J Baron, MA Faller, FC Tenover, RH Yolken (eds), Manual of Clinical Microbiology, 7 ed., ASM Press, Washington, p. 604-613.

Castillo MC de, Nader OM de, Gutiérrez RC de, Ruiz Holgado AP de 1985. Estudio comparativo de métodos de conservación aplicados a Neisseria gonorrhoeae. Bact Clin Argentina 3/4: 54-60.

Clark WS, Brazis AR, Fowler JL, Johns CK, Nelson FE 1978. Standard plate count methods. In EM Marth, Standard Methods for the Examination of Dairy Products, 4th ed., American Public Health Association, Washington, p. 77-94.

Leoni Linders SM, Wolkers WF, Hoekstra FA, Riet K 1997. Effect of added carbohydrates on membrane phase behavior and survival of dried Lactobacillus plantarum. Cryobiology 35: 31-40.

Lievense LC, Verbeeck MAM, Tackema T, Meerdink G, Riet K 1992. Modelling the inactivation of Lactobacillus plantarum during a drying process. Chem Eng Sir 47: 87-97.

Ling GN 1965. Physiology and anatomy of the cell membrane: the physical state of water in the living cell. Fed Proc 24 (Suppl. 15): 103-112.

Major CP 1953. The Effect of the Bacterial Concentration upon Survival at $-20^{\circ} \mathrm{C}$, MSc Thesis, VanderBilt University, Tennessee.

Major CP , Dougal JD, Harrison Jr AP 1955. The effect of the initial cell concentration upon survival of bacteria at $-20^{\circ} \mathrm{C}$. J Bacteriol 69: 244-249.

Meryman HT, Hornblower M 1972. Changes in red blood cells following rapid freezing with extracellular cryoprotective agents. Cryobiology 9:262-267.

Nei T 1981. Mechanism of freezing injury to erythrocytes. Effect of initial cell concentration on the post thaw hemolysis. Cryobiology 18: 229-237.

Pribor DB 1974. PVP contrasted with dextran and the multifactor theory of cryoprotection. Cryobiology 11: 60-72.

Wagman J 1960. Evidence of cytoplasmic membrane injury in the drying of bacteria. J Gen Microbiol 132: 503-512.

Woodcock AH, Thistle MW, Cook WH, Gibbons NE 1941. The ability of sheep's erythrocytes to survive freezing. Canad J Res 19 D: 206-212. 